\title{
Multisystemic tuberculosis presenting with scrofula, intestinal and pulmonary involvement
}

\author{
Ana Margarida Fernandes, Diana Gomes Pedreira, Paula Lopes, Manuela Fera
}

Serviço de Medicina Interna, Hospital S. Bernardo, Centro Hospitalar de Setúbal, E.P.E. Portugal

\section{Correspondence to}

Dr Ana Margarida Fernandes, amargaridagf@gmail.com
CrossMark

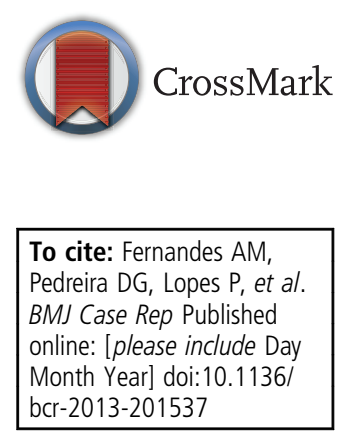

\section{DESCRIPTION}

We present the case of a 69-year-old woman with no relevant medical history who was admitted to the emergency room (ER) with asthenia, anorexia, weight loss, periodic fever and night sweats. Observation revealed a palpable and painful rubbery cervical mass adherent to deep tissue that had been enlarging during the past 3 months. The laboratory workup showed mildly elevated inflammatory parameters (leucocytosis $14000 / \mu \mathrm{L}$ with $78 \%$ neutrophils and $\mathrm{C}$ reactive protein (CRP) $17 \mathrm{mg} / \mathrm{dL}$ ). She was referred to haematology/oncology outpatient consultation with support therapy.

On ambulatory follow-up, bone marrow aspirate and bone biopsy were performed due to lymphoproliferative disease suspicion. The cervical mass was submitted to open biopsy revealing a cavity with pus and caseum-like exudate that was sent to the pathology and microbiology laboratories. HIV serology was negative.

Three weeks later, the patient returned to the ER due to a syncopal episode. She was febrile $\left(38.6^{\circ}\right.$ C), with blood pressure $106 / 68 \mathrm{~mm} \mathrm{Hg}$ and heart rate $91 \mathrm{bpm}$. She had nausea, vomiting and abdominal pain. Her abdomen was tender and painful in the right lower quadrant. She had leucocytosis (17 600), neutrophilia (95.3\%), CRP $32.43 \mathrm{mg} / \mathrm{dL}$, hypokalaemia (K $2.7 \mathrm{mEq} / \mathrm{L}$ ) and hypoproteinaemia with hypoalbuminaemia. Pathology and microbiology results of lymph node biopsy showed a positive smear for acid-fast bacillus and epithelioid granulomas with central necrosis and multinucleated giant cells of Langhans on bone biopsy. The Mycobacterium tuberculosis complex was isolated.

She was started immediately on quadruple antituberculous therapy and was admitted to the medical ward. Chest X-ray showed bilateral interstitial infiltrate suggestive of miliary lesions not present at her

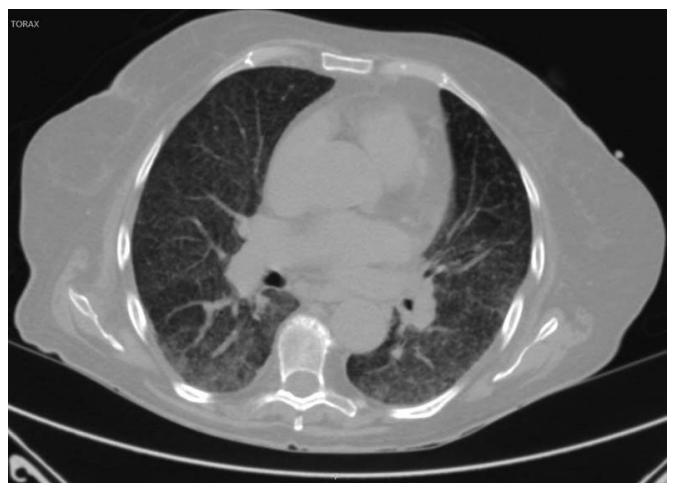

Figure 1 Thorax CT scan showing uniformly sized small nodules randomly distributed throughout both lungs (miliary tuberculosis).

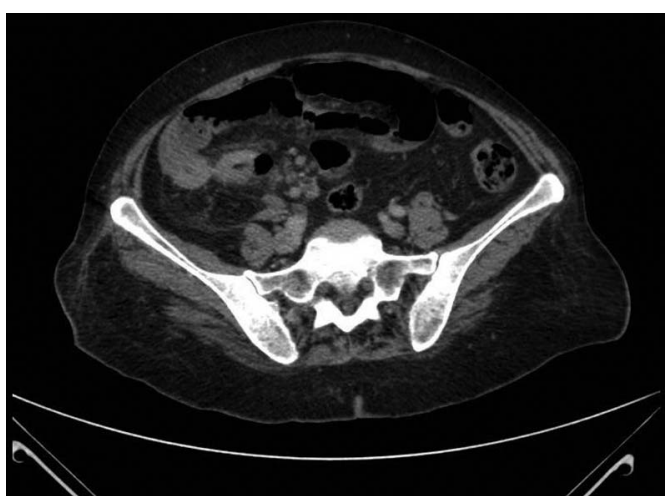

Figure 2 Abdomen CT scan showing a thickening of the ileocecal valve and large mesenteric adenopathies.

first admission. A thoracoabdominal-pelvic CT scan described bilateral micronodular lesions of the lungs and thickening of the walls of the terminal ileum (figures 1 and 2). She was also started on ciprofloxacin for infection on the surgical wound from the open biopsy.

Forty days after the beginning of antituberculous therapy, the patient's status deteriorated with intense abdominal pain and vomiting. Her abdomen was distended but soft with tenderness in the upper quadrants and plain abdominal radiography showed air-fluid levels. Laparotomy was performed revealing intestinal inflammatory adhesions, stenosis of the ileocecal valve and large mesenteric adenopathies (figure 3). Ileocecal resection and anastomosis were performed with apparently clean margins. Three days later, her clinical status deteriorated again and she was operated on again with evidence of anastomotic dehiscence and perforation of the ileum. The pathology result from the surgery samples showed transmural infiltrates with aggregates of epithelioid

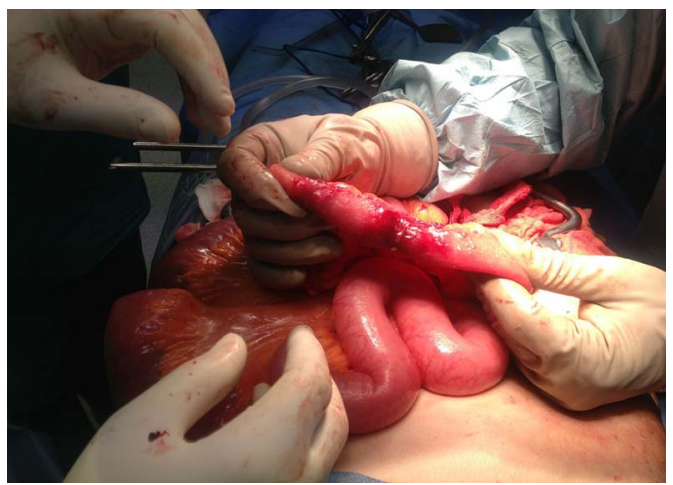

Figure 3 Photograph showing inflammatory changes and a stenosis in a portion of the bowel. 
cells, outlining granulomas without necrosis. The granulomatous process extended to pericolic adipose tissue and reached the ends of the workpiece. An isolated lymph node was consistent with granulomatous lymphadenitis without necrosis.

The patient died a few hours later after the second surgery with the diagnosis of severe sepsis and multiorganic failure due to faecal peritonitis and multisystemic tuberculosis.

\section{Learning points}

- Tuberculosis should always be suspected and never be underestimated. It can affect anybody at any age and requires urgent and aggressive management as it can be fatal. ${ }^{1}$

- Lymphadenitis is the most commonly occurring form of extra pulmonary tuberculosis with cervical adenopathy representing $17 \%$ of cases. ${ }^{2}$

- Complications of intestinal involvement include obstruction, perforation and fistula formation, perforation being the most serious complication, associated with high morbidity and mortality. $^{3}$
Acknowledgements The authors would like to thank Dr Pedro Ferreira, Dr Anabela Neves, Dr Vitor Rigueira and Dr Luis Branco.

Contributors All the authors have contributed actively to the diagnosis and management of this patient, as well as to the writing of this article.

Competing interests None.

Patient consent Obtained.

Provenance and peer review Not commissioned; externally peer reviewed.

\section{REFERENCES}

1 Muquit S, Shah M, Abayajeewa K. A case of miliary tuberculosis presenting with bowel perforation. Emerg Med J 2006;23:e62.

2 Golden MP, Vikram HR. Extrapulmonary tuberculosis: an overview. Am Fam Physician 2005:72:1761-8.

3 Dasgupta A, Singh N, Bhatia A. Abdominal tuberculosis: a histopathological study with special reference to intestinal perforation and mesenteric vasculopathy. J Lab Physicians 2009;1:56-61.

Copyright 2013 BMJ Publishing Group. All rights reserved. For permission to reuse any of this content visit http://group.bmj.com/group/rights-licensing/permissions.

BMJ Case Report Fellows may re-use this article for personal use and teaching without any further permission.

Become a Fellow of BMJ Case Reports today and you can:

- Submit as many cases as you like

- Enjoy fast sympathetic peer review and rapid publication of accepted articles

- Access all the published articles

- Re-use any of the published material for personal use and teaching without further permission

For information on Institutional Fellowships contact consortiasales@bmjgroup.com

Visit casereports.bmj.com for more articles like this and to become a Fellow 